\title{
The bryophytes of Trindade Island, South Atlantic, Brazil
}

\author{
Allan Laid Alkimim Faria ${ }^{1,3}$, Micheline Carvalho-Silva ${ }^{1}$, Denise Pinheiro da Costa $^{2}$ e Paulo Eduardo Aguiar Saraiva Câmara ${ }^{1}$
}

Recebido em 14/03/2012. Aceito em 25/06/2012

\begin{abstract}
RESUMO
(As briófitas da Ilha da Trindade, Atlântico Sul, Brasil) Trindade é uma ilha oceânica brasileira localizada a $1.200 \mathrm{~km}$ a oeste da costa do Brasil entre as coordenadas $20^{\circ} 31^{\prime} 30^{\prime \prime}$ S e 29 $19^{\prime} 30^{\prime \prime}$ W. A ilha emergiu da zona abissal cerca de 3 milhões de anos, com altitude máxima de $620 \mathrm{~m}$ e uma área de $9,28 \mathrm{~km}^{2}$. Sua flora fanerógama é relativamente conhecida, sendo praticamente não tendo dados sobre a flora de briófitas. Foram realizadas quatro expedições entre os anos de 2010 e 2011 e cerca de 431 espécimes coletados. O resultado mostrou 32 espécies de briófitas, das quais 20 são hepáticas distribuídas em seis famílias, com 11 espécies de Lejeuneaceae e quatro de Frullaniaceae. Na divisão dos musgos foi representado com 11 espécies distribuídos em oito famílias sendo a mais diversificadas com duas espécies: Fissidentaceae, Leocobryaceae e Pottiaceae. Na divisão dos antóceros apenas uma espécie foi encontrada. Foram fornecidos chaves de identificação, discussão de cada espécie. A flora da Trindade provavelmente se originou do ameaçado bioma Mata Atlântica com implicações para sua conservação.
\end{abstract}

Palavras-chave: Antóceros, conservação, flora, hepáticas, musgos

\begin{abstract}
(The bryophytes of Trindade Island, South Atlantic, Brazil) Trindade is a Brazilian oceanic island located about 1,200 Km east of the Brazilian coast (between $20^{\circ} 31^{\prime} 30^{\prime \prime} \mathrm{S}, 29^{\circ} 19^{\prime} 30^{\prime \prime} \mathrm{W}$ ). The island originated from the abissal zone about 3 million years ago, has a maximum altitude of 620 meters and an area of $9.28 \mathrm{Km}^{2}$. Even though the fanerogamic flora is known, there were virtually no data on the bryophyte flora. Four expeditions to the island were carried out during two years and approximately 431 specimens collected. This work presents the Bryoflora of this island, which comprises 32 species, including 20 species of liverworts distributed among six families; the most speciose being Lejeuneaceae with 11 species and Frullaniaceae with four. There are also 11 species of mosses distributed among eight families, the most diverse being Fissidentaceae, Leocobryaceae and Pottiaceae with two species each. Only one species of hornworts was found. The bryophyte flora of Trindade most likely originated from the threatened Atlantic Forest of southeastern Brazil and, therefore, has conservation implications. Keys and comments are provided.
\end{abstract}

Key words: Conservation, flora, hornworts, liverworts, mosses

\section{Introduction}

Trindade is an oceanic island located in the south Atlantic, between $20^{\circ} 31^{\prime} 30^{\prime \prime} \mathrm{S}$ and $29^{\circ} 19^{\prime} 30^{\prime \prime} \mathrm{W}$, and is about $1,200 \mathrm{Km}$ east from the coast of Brazil (Fig.1). The island is $9.28 \mathrm{Km}^{2}$ and arouse from the abyssal zone about 3 million years ago as result of volcanic activity. According to Alves (1998), Pinheiro et al. (2009), Serafini et al. (2010) and Silva \& Alves (2011), the last volcanic activity was about 50,000 years ago. Oceanic depths around the island are estimated to be $5,800 \mathrm{~m}$ and the highest points on the island are Desejado Hill (620 m) and nearby São Bonifácio Hill (570 m).
The relatively high hills on the island are responsible for the presence of three fresh water creeks as well as a small waterfall. Of the four oceanic islands in Brazil, Trindade is the only to have freshwater.

The climate of the island is tropical oceanic and semiarid with an average annual precipitation of $923 \mathrm{~mm}$ and temperature of $25.2^{\circ} \mathrm{C}$ (Alves 1998).

The Portuguese sailor João da Nova first discovered the island in 1502. The island remained uninhabited until 1730 when Azoreans tried (unsuccessfully) to colonize it; after 65 years (1795) they left Trindade leaving behind goats, pigs and dogs that eventually became feral. The goats

\footnotetext{
${ }^{1}$ Universidade de Brasília, Departamento de Botânica, Campus Universitario Darcy Ribeiro, Brasília, DF, Brazil

${ }^{2}$ Instituto de Pesquisas Jardim Botânico do Rio de Janeiro, Rio de Janeiro, RJ, Brazil

${ }_{3}^{3}$ Author for correspondence: allanlaid@gmail.com
} 


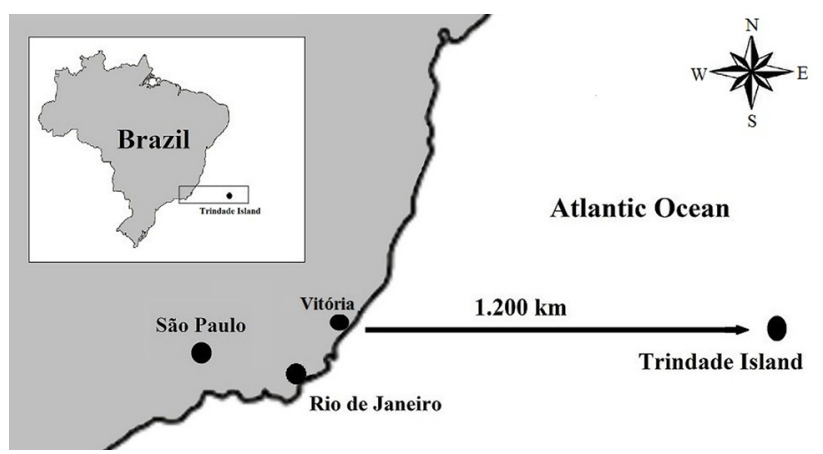

Figure 1. Distance between Trindade and the coast of South America.

were particularly successful as their population grew and became a main environmental problem due to the grazing that destroyed a great part of the original vegetation (Alves 1998; Silva \& Alves 2011).

Since this time, the island was occupied between 1822 and 1889 when it was mostly used by slave traders and pirates. In 1895 the British Crown claimed it but the Brazilians gained it back through diplomacy in 1896. The island was used as a Brazilian political prison in 1924, and 1926 it was again abandoned. It was again shortly occupied during World War I and WW II, but at the end of WWII the island was abandoned. Permanent occupation came only in 1957 when Brazil built a small navy garrison that is still active. During the 1990s the Brazilian Navy started a program to eliminate the goats and other feral animals, and, as far as it is known, they were fully eliminated in 1998 (Silva \& Alves 2011).

After the elimination of the goats, the vegetation visibly changed towards what is believed to be a closer version to its original size and composition, and there are currently studies about the flowering plant vegetation recovery (Martins \& Alves 2007).

Recently (2010) the Navy built a science facility on Trindade and the Brazilian funding agencies started supporting regular research activity on the island. However access to the island remains very difficult, and special permits are needed from the Navy. There are no airstrips or seaports, and the only way to travel to the island is on warships that visit Trindade every two months in order to leave supplies and render the garrison. It usually takes 3-5 days to reach the island from the seaport of Rio de Janeiro. The vessel needs to dock far from the coast and helicopters or small boats are used to reach the island.

Very little is known about the vegetation of Trindade that existed prior to its occupation in 1957; as said, the original vegetation was severely damaged by the goats. The first botanical collections were made by Edmund Halley in 1700 (which have never been studied), and J.D. Hooker collected there in 1839 . It is believed that more than $80 \%$ of the island was covered by forests of Colubrina glandulosa Perk before the introduction of the goats. For a more complete history of botanical expeditions to Trindade see Alves (1998).
Currently the island has an extensive grassy vegetation (about $60 \%$ are open fields dominated by Poaceae and Cyperaceae), and only about $5 \%$ is covered by forest vegetation (Fig.2), especially the so-called "giant ferns forest" that are located above $400 \mathrm{~m}$ and mainly composed of the endemic fern Cyathea copelandii Kuhn \& Luerss with some representatives of Colubrina glandulosa (Alves 1998; Silva \& Alves 2011).

According to Alves (2006), there are currently 130 species of vascular plants, which includes five phanerogam endemics (Cyperus atlanticus Hemsl; Bulbostylis nesiotis (Hemsl.) C.B. Clarke;Achyrocline disjuncta Hemsl.; Plantago trinitatis Rahn. and Peperomia beckeri E.F.Guim. \& R.J.V.Alves) there are, also four endemic ferns (Pleopeltis trindadensis (Brade) Salino; Cyathea copelandii Kuhn \& Luerssen; Doryopteris campos-portoi Brade; Dryopteris novaena Brade), and 12 freshwater algae have been reported (Alves 1998). The island is also home to many endemic animals such as invertebrates, fishes, birds and mollusks besides being one of the most populated sites for marine turtle (Chelonia mydas) reproduction in the South Atlantic (Alves 1998; Almeida et al. 2011; Dias et al. 2010; Leal \& Bouchet 1991; Pinheiro et al. 2009; Rangel et al. 2004).

Even though much is known about the vascular flora, only six species of bryophytes were reported for the island (Alves 1998), which were collected by fanerogamic botanists.

In this paper we present a more detailed list of the little known bryophyte flora of Trindade Island, including identification keys, comments and a brief comparison with other South Atlantic islands, in an effort to better understand the distribution patterns across these islands. A deeper investigation among Trindade vegetation and other South Atlantic islands is underway and will be presented elsewhere. Also data presented here contribute to understanding the successional

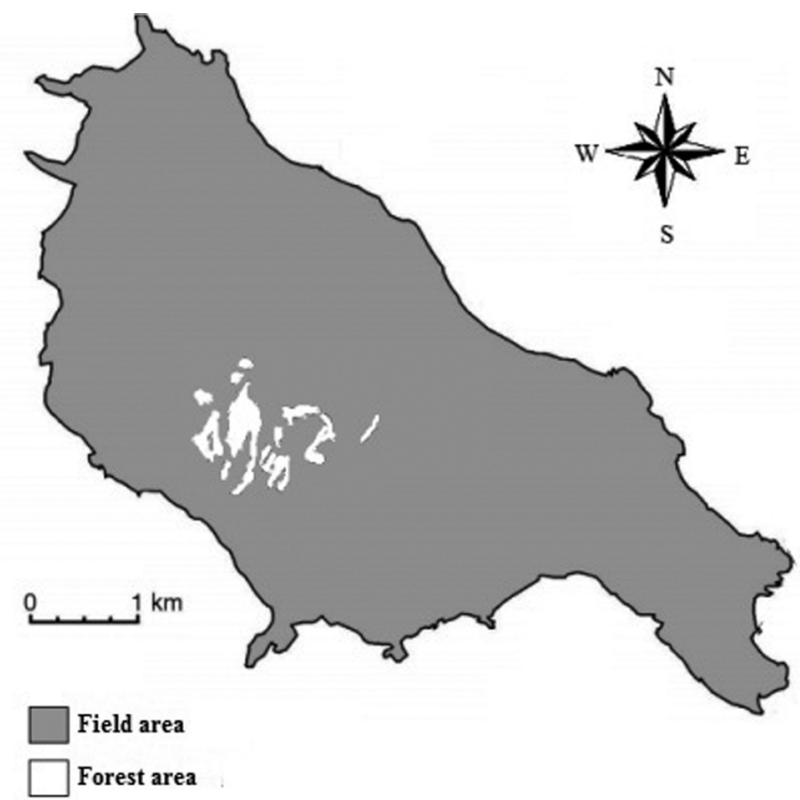

Figure 2. Map with the vegetation of Trindade, note the fragmented forested areas present on top of the hills. 
changes that the vegetation has gone through since the goats were exterminated. Consequently, it is our hope that this work will help with the conservation initiatives of Trindade.

\section{Materials and methods}

We visited the herbaria $\mathrm{R}$ and SP, where the few cited collections of mosses from Trindade are archived, and also made four field expeditions to Trindade between 2010 and 2011. A total of 431 plant samples were collected during the field trips, and all of the collected material was deposited at UB. Material was mounted on slides with Hoyer solution (Anderson 1954) and identified using literature; when needed material was sent to specialists for identification. Geographic distribution follows Costa et al. (2011) and Gradstein \& Costa (2003). Under the specimens examined, only one voucher per site is cited. Classification follows Goffinet et al. (2009) for mosses, Crandal-Stoler et al. (2009) for hepatics and Renzaglia et al. (2009) for anthoceros. The figures of the maps were produced in Adobe Photoshop CS6 for Windows 7 based in Alves (1998).

\section{Results}

A total of 32 species of Bryophytes were reported, of which only one represents Anthocerotophyta (Hornworts), 20 are species of Marchantiophyta (Liverworts) and 11 are species of Bryophyta (Mosses). Among the Liverworts the most speciose families were Lejeuneaceae with 11 species and Frullaniaceae with four. The most speciose families of mosses were Fissidentaceae, Leocobryaceae and Pottiaceae, with two species each, followed by other families with one species each.

\section{Key to Marchantiophyta}

1.Plant thalose

Riccia membranacea

1.Plant foliose

2.Underleaf present

3.Leaf with 2 ciliate teeth

Chiloscyphus martianus

3.Leaf margins without ciliate teeth, entire

4.Stylus present

5.Leaf mucronate apex

Frullania beyrichiana

5.Leaf rounded apex

Frullania gibbosa

6.Lobules laminate

6.Lobules not laminate

7.Lobules oblique

Frullania caulisequa

7.Lobules erect Frullania kunzei

4.Stylus absent

8.Underleaf entire

9.Leaf margin dentate, at least near apex

10.Ventral merophyte with 4 or more cells wide

Marchesinia brachiata

10.Ventral merophyte with 2 cell wide Acanthocoleus aberrans

9.Leaf margin entire

11.Lobules inflated strongly inrolled margin

Anoplolejeunea conferta

11.Lobules not inflated or not inrolled margin

12.Cells with cordate trigones

13.Lobules with 0 -2 teeth

13.Lobules with 3-11 teeth

Schiffneriolejeunea polycarpa

. Frullanoides corticalis

12.Cells with triradiate trigones

14.Lobules $1 / 3-1 / 2$ of leaf length

Leucolejeunea unciloba

14.Lobules $1 / 10-1 / 4$ of leaf length

Symbiezidium barbiflorum

8.Underleaf bifid

15. Plants up to $0,5 \mathrm{~mm}$ wide; leaf suberect convergent to stem

Microlejeunea bullata

15.Plants larger than $0,5 \mathrm{~mm}$ wide; leaf expanded divergent to stem

16.Leaf lobes sub-erect; lobules $1 / 10-1 / 2$ leaf length

17.Underleaf obovate.

Cheilolejeunea rigidula

17.Underleaf ovate Cheilolejeunea trifaria

16.Leaf lobes spreading; lobules less than $1 / 3$ leaf length

18.Plants up to $0,8 \mathrm{~mm}$ width; Underleaf distant, base cuneate a rounded.

Lejeunea caespitosa 
18.Plants above $0,8 \mathrm{~mm}$ width; Underleaf contiguous, base straight to slightly auriculate Lejeunea flava

2.Underleaf absent

20.Sucubous leaves, margins crispate-undulate

Plagiochila corrugata

20.Icubous leaves, margins entire Jungermannia amoena

Key to Bryophyta

1.Plant pleurocarpous

Isopterygium tenerifolium

1.Plant acrocarpous

2.Leaves spiralate without vaginant laminae

3.Leaves with alar or hyaline cells

4.Costa ca $1 / 2$ of leaf basis

5.Leaves with hyaline apex.

Campylopus pilifer

5.Leaves without hyaline apex

6.Leaves narrow lanceolate and minutely serrulate; costa large $1 / 2$ the leaf base; alar cells retangular Campylopus fragilis ssp. fragiliformis

6.Leaves large ovade-lanceolate and not serrulate; costa narrow 1/5 the width of the leaf base; alar cells quadrate

Leptotrichella lindigiana

4. Costa less than $1 / 2$ of leaf basis

7.Hyaline cells bigger than green cells

Calymperes tenerum

7.Hyaline cells same as green cells

8.Leaf margin present; pluripapillose leaf cells

Barbula indica

8. Leaf margin absent; smooth leaf cells.

3.Leaves without alar cells or hyaline cells half to the apex

9.Leaves gray or silver, margin smooth and bordered

9.Leaves green, margin serrate not bordered

Bryum argenteum

Philonotis uncinata

2.Leaves distichous with vaginant laminae

10.Leaves with unbordered margins and papillose cells.

10.Leaves with bordered margins and smooth cells

Fissidens hornschuchii

Fissidens zollingeri

\section{Marchantiophyta}

\section{Frullaniaceae}

Frullania beyrichiana (Lehm. \& Lindenb.) Lehm. \& Lindenb., Syn. Hepat. 460. 1845.

Of neotropical distribution, this species was recorded only by Alves (1998), was not found again during any of our field trips and is probably locally extinct. This species differs from other species of Frullania in Trindade because its leaves have a mucronate apex. In Brazil it is known mostly from the Atlantic Forest, where it grows on bark and rock, and is reported from Acre, Bahia, Goiás, Espírito Santo, Mato Grosso, Minas Gerais, Pará, Pernambuco, Rio de Janeiro, Rio Grande do Sul and São Paulo.

Specimen examined. BrasiL: Ilha da Trindade: sine loco, A1ves 4701 (R).

Frullania caulisequa (Nees) Ness, Syn. Hepat. 448. 1845.

This neotropical species is found on Trindade, commonly above $200 \mathrm{~m}$, on tree trunks, twigs, and occasionally in giant fern forests on rocks or on soil, both in sunny and shaded areas. On the continent it is mostly found on dead logs and bark and occasionally on rocks (to $1,000 \mathrm{~m}$ ). It differs from the other species of Frullania on Trindade by the presence of lobules that are divergent from the stem. Reported from Acre, Alagoas, Bahia, Ceará, Distrito Federal, Espírito Santo, Goiás, Mato Grosso, Pará, Paraíba, Pernambuco, Rio de Janeiro, Rio Grande do Sul, Roraima, Santa Catarina, São Paulo and Sergipe.

Specimens examined. BrasiL. Ilha da Trindade: Floresta de Samambaias Gigantes, 6/VI/10, Faria 80 (UB); trilha do Pico do Desejado, 05/XII/10, Faria 214 (UB); Pico do Desejado, 10/III/11, Faria 588 (UB).

Frullania gibbosa Nees, Ann. Sci. Nat. Bot., sér. 2, 14: 333. 1840

This neotropical species is found on Trindade, above 400 $\mathrm{m}$, on bark. On the continent it is found to $1,200 \mathrm{~m}$ in the same kind of habitats as well as on rocks in very dry areas (such as in restinga). It differs from all other Frullania on Trindade by its inflated, globulose lobes. In Brazil it is well distributed and reported from Acre, Amazonas, Bahia, Distrito Federal, Goiás, Espírito Santo, Mato Grosso, Mato Grosso do Sul, Minas Gerais, Pará, Paraíba, Pernambuco, Rio de Janeiro, Roraima and Santa Catarina. 
Specimens examined. BrasiL. Ilha da Trindade: Floresta de Samambaias Gigantes, 27/II/11, Faria 361 (UB).

Frullania kunzei Lehm. \& Lindenb., Syn. Hepat. 449. 1845.

This species is found on Trindade only in the so-called giant fern forest and is restricted to bark and rocks at altitudes above $250 \mathrm{~m}$. This neotropical species is very common on the continent where it inhabits the same kind of substrata and is found up to $2,400 \mathrm{~m}$. It has divergent lobes with a stem that differs from other Frullania in Trindade. In Brazil it is widespread and reported from Acre, Bahia, Ceará, Espírito Santo, Mato Grosso, Pará, Paraíba, Paraná, Pernambuco, Rio de Janeiro, Rio Grande do Sul, São Paulo and Sergipe.

Specimens examined. Brasil. Ilha da Trindade: Pico do Desejado, 27/II/11, Faria 348 (UB); trilha do Pico do Desejado, 26/III/11, Faria 584 (UB).

\section{Geocalycaceae}

Chiloscyphus martianus (Nees) J.J. Engel \& R.M. Schust., Nova Hedwigia 39: 419. 1984.[1985].

This species, which has a neotropical and African distribution, is found on Trindade on dead ferns in shaded areas above $400 \mathrm{~m}$. It is most often associated with Isopterygium tenerifolium and is characterized by its leaves with a cornate apex. On the continent it is found on logs and soil. In Brazil it occurs up to $1,850 \mathrm{~m}$ high, is widespread, and reported from Acre, Amapá, Amazonas, Bahia, Ceará, Distrito Federal, Goiás, Mato Grosso, Mato Grosso do Sul, Minas Gerais, Pará, Paraná, Pernambuco, Rio de Janeiro, Rio Grande do Sul, São Paulo and Santa Catarina.

Specimen examined. BRAsIL. Ilha da Trindade: Floresta de Samambaias Gigantes, 27/II/11, Faria 364 (UB).

\section{Jungermanniaceae}

Jungermannia amoena Lindenb. \& Göttsche, Syn. Hepat. 674. 1847.

This species has a neotropical distribuition and was found on Trindade inhabiting the edges of the giant fern forest, on the ground at $400 \mathrm{~m}$. On the continent it is very common in shaded vegetation and soil along rivers up to $2,500 \mathrm{~m}$. On Trindade it is quite rare and was only found at $400 \mathrm{~m}$. This is species is characterized by sucubus leaves and an absence of underleaves. In Brazil it is reported from Espírito Santo, Minas Gerais, Pará, Piauí, Rio de Janeiro, Santa Catarina and São Paulo.

Specimen examined. Brasil. Ilha da Trindade: Pico do Desejado, 05/XII/10, Faria 209 (UB).

\section{Lejeuneaceae}

Acanthocoleus aberrans (Lindenb. \& Göttsche) Kruijt, Bryophyt. Biblioth. 36: 62. 1988.

This species has a neotropical and African distribuition, mainly inhabits the giant fern forest that is commonly found at $500 \mathrm{~m}$ and occasionally is found in open areas at $180 \mathrm{~m}$. This is the only other species of liverwort that occurs in open and forested areas; however, it is more abundant in the forests. Interestingly, in open areas it shows a dark coloration whereas in forest areas it is a shiny light green. In Brazil it grows on the same substrates (bark and rock in rather dry woodlands and scrub, and on isolated trees, and occasionally on soil), between $50-200 \mathrm{~m}$, and is reported from Alagoas, Distrito Federal, Espírito Santo, Minas Gerais, Paraná, Rio de Janeiro, Rio Grande do Sul, Santa Catarina and São Paulo.

Specimens examined. Brasil. Ilha da Trindade: Pico da Bandeira, 23/II/11, Faria 301 (UB); Pico Pão de Acúcar, 23/ II/11, Faria 304 (UB); Sine Loco, 22/X/11 Dittrich 1745 (UB).

Cheilolejeunea rigidula (Mont.) R.M. Schust., Castanea 36: 102. 1971.

This species has a neotropical and African distribution. On Trindade it inhabits the giant fern forest at $300 \mathrm{~m}$, in places with higher humidity and shade, on trunks of living trees. On the continent it is very common on bark and in the canopy of trees in lowland rain forest, scrub, restinga, mangroves, plantations, and also on rocks, up to $1,000 \mathrm{~m}$. It differs from Cheilolejeunea trifaria by its underleaves with an acute apex. In Brazil it is reported from Acre, Alagoas, Amapá, Amazonas, Bahia, Ceará, Espírito Santo, Goiás, Maranhão, Minas Gerais, Pará, Paraíba, Paraná, Pernambuco, Rio de Janeiro, Roraima, Santa Catarina, São Paulo, Sergipe and Tocantins.

Specimens examined. Brasil. Ilha da Trindade: Floresta de Samambaias Gigantes, 27/II/11, Faria 384 (UB); Fazendinha, Faria 604 (UB); Sine Loco, 22/X/11, Dittrich 1748 (UB).

Cheilolejeunea trifaria (Reinw. Blume \& Nees.) Mizut., J. Hattori Bot. Lab. 27: 1321964.

This species has a pantropical distribution. On Trindade it was only found in the giant fern forest, above $250 \mathrm{~m}$, on tree trunks. On the continent it is found up to $1,000 \mathrm{~m}$, on rocks, bark, or in shaded places along roads. It differs from Cheilolejeunea rigidula by its much larger (2x the width) underleaves, (see comments under Cheilolejeunea rigidula). In Brazil it is reported from Acre, Amazonas, Bahia, Ceará, Distrito Federal, Espírito Santo, Goiás, Mato Grosso, Mato Grosso do Sul, Minas Gerais, Pará, Paraíba, Paraná, Pernambuco, Rio de Janeiro, Roraima and São Paulo.

Specimens examined. Brasil. Ilha da Trindade: Floresta de Samambaias Gigantes, 27/II/11, Faria 385 (UB); Sine loco, Alves 4459 (R); Sine loco, Alves 4474 (R).

Frullanoides corticalis (Lehm. \& Lindenb.) Slageren, Meded. Bot. Mus. Herb. Rijks Univ. Utrecht 544: 84. 1985.

This species has a pantropical distribution. On Trindade it inhabits areas of forest, above $400 \mathrm{~m}$, on tree trunks. On the continent it is commonly found on bark and rocks in dry forests, mangroves, plantations and on isolated trees in villages, above $500 \mathrm{~m}$. It can be recognized by its underleaves that are not auriculate and straight insertion line. In Brazil 
it is reported from Bahia, Mato Grosso, Minas Gerais, Rio de Janeiro and Roraima.

Specimen examined. Brasil. Ilha da Trindade: Pico do Desejado, 27/II/11, Faria 358 (UB).

Lejeunea caespitosa Lindenb., Syn. Hepat. 382. 1845.

This species has a neotropical and African distribution. On Trindade it inhabits areas of transition between field and forest as well as the giant fern forest, above $250 \mathrm{~m}$; it grows only on dead ferns. It can be recognized by its broadly Ushaped, sinus underleaf. On the continent it lives on bark and occasionally on leaves and rocks, from 0-800 m. In Brazil it is reported from Acre, Pará, Rio de Janeiro and São Paulo.

Specimen examined. Brasil. Ilha da Trindade: trilha do Pico do Desejado, 06/VI/10, Faria 93 (UB).

Lejeunea flava (Sw.) Ness, Naturgesch. Eur. Leberm. 3: 277.1838.

This species has a pantropical distribution. On Trindade it inhabits very moist and shady areas, like the giant fern forest, above $280 \mathrm{~m}$ high, and is most often found on soil, or colonizing the remains of dead ferns. On the mainland it is commonly found on bark of trees and rocks in tropical forests, dunes, marshes, parks, and also on soil, to 2,400 m. This species is easy to identify due to its yellowish-green colour and cuneate underleaf bases. In Brazil is widespread and reported from Acre, Alagoas, Amazonas, Bahia, Ceará, Distrito Federal, Espírito Santo, Goiás, Mato Grosso, Mato Grosso do Sul, Minas Gerais, Pará, Paraíba, Paraná, Pernambuco, Rio de Janeiro, Rio Grande do Sul, Roraima, Santa Catarina, São Paulo, Sergipe and Tocantins.

Specimens examined. Brasil. Ilha da Trindade: Platô do Pico do Desejado, 06/VI/10, Faria 81 (UB); Floresta de Samambaias Gigantes, 27/II/11, Faria 368 (UB).

Leucolejeunea unciloba (Lindenb.) A. Evans, Torreya 7: 228. 1907.

This species has a neotropical and African distribution. On Trindade it inhabits the bark of living trees, at $300 \mathrm{~m}$, and is scarcely distributed in the forest. It is very common on the continent where it can be found on the bark of dead trees or rocks where there is plenty of moisture and shade, as well as in salt marshes and mangroves, to $1,300 \mathrm{~m}$. This species can be recognized by its leaves with folded margins. In Brazil it is reported from Acre, Amazonas, Bahia, Ceará, Espírito Santo, Minas Gerais, Pará, Paraíba, Pernambuco, Rio de Janeiro, Rio Grande do Sul, Santa Catarina and São Paulo.

Specimens examined. Brasil. Ilha da Trindade: Floresta de Samambaias Gigantes, 06/VI/10, Faria 80 (UB); Fazendinha, 27/II/11, Faria 360 (UB).

Marchesinia brachiata (Sw.) Schiffner, in Engler \& Prantl, Nat. Pflanzenfam. 1, 3: 128. 1893.

This species has a neotropical and African distribution. It was found on the island only by Alves (1998) and has not been recollected since; it may be locally extinct. Accord- ing to Gradstein \& Costa (2003), it lives on bark, rocks in tropical forest and plantations. It is commonly found on the continent and is characterized by its leaves that are ovate-oblong, with apices that are rounded to acuminate with elongated, apiculate lobes and rounded underleaves. In Brazil it is reported from Bahia, Ceará, Espírito Santo, Mato Grosso, Minas Gerais, Paraná, Pernambuco, Rio de Janeiro, Roraima, Santa Catarina and São Paulo.

Specimen examined. Brasil. Ilha da Trindade: Sine loco, Alves 4701 (R).

Microlejeunea bullata (Taylor) Steph., Sp. Hepat. 5: 824. 1915.

This species has a neotropical distribution. On Trindade it inhabits the giant fern forest, above $400 \mathrm{~m}$. It is usually associated with Frullania caulisequa, and grows on tree trunks. On the continent it is commonly found on bark in rain forest and scrub, as well as in restinga, to $2,400 \mathrm{~m}$. It can be easily identified due to its very small lobes that are also distant from each other. In Brazil is reported from Acre, Amazonas, Bahia, Ceará, Distrito Federal, Espírito Santo, Goiás, Maranhão, Mato Grosso, Mato Grosso do Sul, Minas Gerais, Paraná, Pernambuco, Rio de Janeiro, Rio Grande do Norte, Rio Grande do Sul, Roraima, Santa Catarina, São Paulo and Sergipe.

Specimens examined. Brasil. Ilha da Trindade: trilha do Pico do Desejado, 06/VI/10, Faria 80 (UB); Pico do Desejado, 05/VII/10, Faria 215 (UB).

Schiffneriolejeunea polycarpa (Nees) Gradst., J. Hattori Bot. Lab. 38: 335. 1974.

A species with unusual distribution; occurring in the neotropics, Africa and India. On Trindade it dwells in the shadows of rocks and dry places, sometimes on tree trunks, above $300 \mathrm{~m}$. It is easily recognized by its dark color (dark green to black). On the continent it is found in xeromorphic places on rotten wood, bark, very dry woodlands, roadside trees, on bark and rotten wood in open, rather dry woodlands, scrub, restinga, plantations, and on roadside trees, occasionally in rain forest, to $1,000 \mathrm{~m}$. In Brazil it is widespread and reported from Amazonas, Bahia, Espírito Santo, Goiás, Minas Gerais, Pará, Pernambuco, Rio de Janeiro, Rio Grande do Sul, Santa Catarina and São Paulo.

Specimens examined. Brasil. Ilha da Trindade: Pico do Desejado, 05/12/10, Faria 215(UB); Floresta de Samambaias Gigantes, 27/II/11, Faria 367 (UB).

Symbiezidium barbiflorum (Lindenb. \& Göttsche) A. Evans, Bull. Torrey Bot. Club 34: 540. 1908.

This species has neotropical distribution and occurs only in open field crevices of shady rocks, above $230 \mathrm{~m}$. Plants are very dark green or black in colour and are not very common on Trindade Island. On the continent it is found on decaying tree trunks and green leaves in tropical forests, as well as restinga, branches, twigs and decaying wood, to 1,500 m. In Brazil is reported from Acre, Amazonas, Bahia, 
Espírito Santo, Pará, Pernambuco, Rio de Janeiro, Santa Catarina and São Paulo.

Specimen examined. Brasil. Ilha da Trindade: Pico Pão de Açúcar, 05/XII/10, Faria 218 (UB).

\section{Plagiochilaceae}

Plagiochila corrugata (Nees) Nees \& Mont., Ann. Sci. Nat., Bot., sér. 2, 5: 52. 1836.

This species has a neotropical distribution. On Trindade it dwells in the giant fern forest, above $400 \mathrm{~m}$, where it grows on tree trunks and soil. It is usually associated with species of Lejeuneaceae. On the mainland it is commonly found on bark in evergreen forests of coastal Brazil, as well as in scrub and restinga, to $2,300 \mathrm{~m}$. This species is easily recognized by its recurved margin. In Brazil it is reported from Bahia, Espírito Santo, Minas Gerais, Paraná, Pernambuco, Rio de Janeiro, Rio Grande do Sul, Santa Catarina and São Paulo.

Specimens examined. Brasil. Ilha da Trindade: Floresta de Samambaias Gigantes, 07/XII/10, Faria 211 (UB).

\section{Ricciaceae}

Riccia membranacea Göttsche, Lindenb. \& Nees., Syn. Hepat.: 608. 1846.

A species with a neotropical and African distribution. On Trindade it is found only in streams (on the bed and margin), on soil and rocks where there is enough moisture, and also among small populations of Cyperaceae, to 200 $\mathrm{m}$. On the mainland it inhabits bare soil along rivers and ponds, in open places, to $1,000 \mathrm{~m}$. This was the only talose species of Marchantiophyta found on the island and is most often associated with Anthoceros punctatus (the only representative of the division Anthocerophyta on Trindade). In Brazil it is reported from Acre, Amazonas, Espírito Santo, Mato Grosso, Pará, Pernambuco, Rio Grande do Sul and São Paulo.

Specimens examined. Brasil. Ilha da Trindade: margem do córrego na trilha do Pico do Desejado, 06/VI/10, Faria 74 (UB); margem do córrego na trilha do Pico do Desejado, 16/II/11, Faria 239 (UB).

\section{Bryophyta}

\section{Bartramiaceae}

Philonotis uncinata (Schwägr.) Brid., Bryol. Univ. 2: 221. 1827.

This cosmopolitan species was found on Trindade on beds and banks of streams on wet soil and rocks. On the island it is widely distributed in lowland areas were it is easily found; it does not occur in the forest areas that are on the top of the hills. This species can be recognized by the presence of prorulose apex cells and by the presence of costate leaves lacking a border. In continental Brazil it occupies the same substrata and can be found up to $1,600 \mathrm{~m}$. It is present in the states of Acre, Amapá, Amazonas, Bahia, Distrito
Federal, Espírito Santo, Goiás, Mato Grosso, Mato Grosso do Sul, Minas Gerais, Pará, Paraíba, Paraná, Pernambuco, Piauí, Rio de Janeiro, Rio Grande do Sul, Roraima, Santa Catarina, São Paulo and Tocantins.

Specimens examined. Brasil. Ilha da Trindade: Pico da Bandeira, 06/VI/10, Faria 64 (UB); Morro Vermelho, 27/ II/11, Faria 338 (UB); Farilhões, 06/III/11, Faria 462 (UB); trilha da praia do "M", 06/III/11, Faria 446 (UB); trilha dos Farilhões, 06/III/11, Faria 462 (UB); Sine Loco, 22/X/11, Dittrich 1734 (UB).

\section{Bryaceae}

Bryum argenteum Hedw., Sp. Musc. 181. 1801.

This species is cosmopolitan. On Trindade it occurs in open fields, on soil and in rock crevices, starting at $150 \mathrm{~m}$. It is easily recognized by its leaves that have green cells in the lower half and are hyaline in the upper half. This species has a wide distribution on the continent, and is frequently found in disturbed places. On Trindad Island it colonizes crevices of volcanic rocks. In Brazil it is reported from Alagoas, Amazonas, Bahia, Ceará, Distrito Federal, Espírito Santo, Goiás, Mato Grosso, Minas Gerais, Paraíba, Paraná, Pernambuco, Rio de Janeiro, Rio Grande do Sul, Roraima, Santa Catarina and São Paulo.

Specimens examined. Brasil. Ilha da Trindade: Pico da Bandeira, 05/XII/10, Faria 209 (UB); Ponta Verde, 27/II/11, Faria 326 (UB); Pico da Bandeira, 26/III/11, Faria 596 (UB).

\section{Calymperaceae}

Calymperes tenerum Müll. Hal., Linnaea 37: 174. 1872.

This species has a pantropical distribution. On Trindade it is found on soils and volcanic rocks, over $100 \mathrm{~m}$, and is associated with Fissidens hornoschuchii. On the continent it occurs on the bark of dead trees in coastal regions from near sea level to $200 \mathrm{~m}$. It can be recognized by its papillose costa. Although it is pantropical, in Brazil it is restricted to Minas Gerais, Rio de Janeiro, São Paulo and Tocantins.

Specimen examined. Brasil. Ilha da Trindade: Pico da Bandeira, 23/II/11, Faria 297 (UB).

\section{Dicranaceae}

Leptotrichella lindigiana (Hampe) Ochryra, Fragm. Flor.Geobot. 42:563.1997.

This species has a neotropical distribution. On Trindade it is found at the top of Pico do Desejado Hill, above 400 $\mathrm{m}$, and inhabits the soil under vegetation and trail edges of the giant fern forest. This species can be differentiated from others of Trindade by its costa that occupies less than $1 / 2$ of its base width. On the continent it occurs on soil, up to $2,000 \mathrm{~m}$. This record needs to be further investigated because this species was not cited for Brazil by Costa et al. (2011) but was reported by Yano (2011) for Bahia (Ilhéus) and Ceará (Guaramiranga).

Even having this odd distribution, the presence of this species on Trindade is not unexpected because it occurs in 
southern Bahia, in a costal region that is also dominated by remnants of Atlantic Forest, similar to those in SE Brazil.

Specimen examined. Brasil. Ilha da Trindade: platô Pico do Desejado, 06/VI/10, Faria 71 (UB).

\section{Fissidentaceae}

Fissidens hornschuchii Mont., Ann. Sci. Nat., Bot., sér. 2, 14: 342. 1840.

This species has a neotropical distribution. On Trindade it is found on the beds and banks of streams on wet soil and rock. On the island it is widely distributed lowlands it can be easily found. It does not occur in the forest on the top of the hills. In Brazil it occurs on sandy wet soil in pasture, occupies the same substrate and can be found to $1,600 \mathrm{~m}$. This species was initially listed by Alves (1998) as Fissidens elegans; however, a more detailed study revealed that is was $F$. hornschuchii. It can be recognized by its leaves with borderless papillose cells and strong costa. It is present in the states of Alagoas, Amazonas, Bahia, Ceará, Distrito Federal, Espírito Santo, Goiás, Maranhão, Minas Gerais, Mato Grosso, Mato Grosso do Sul, Pará, Paraná, Pernambuco, Piauí, Paraná, Rio de Janeiro, Rio Grande do Sul, Santa Catarina and São Paulo.

Specimens examined. Brasil. Ilha da Trindade: trilha do Pico do Desejado, 06/VI/10, Faria 82 (UB); Morro Vermelho, 27/II/11, Faria 333 (UB); Ponta do Noroeste, 28/ II/11, Faria 425 (UB); Praia do "M", 06/III/11, Faria 457 (UB); Sine Loco, 22/X/11, Dittrich 1736 (UB); Sine Loco, Alves 4695 (R).

Fissidens zollingeri Mont., Ann. Sci. Nat. Bot. 3, 4: 114. 1845.

This species has a pantropical distribution. On Trindade it occurs along the edges of the giant fern forest, above 400 $\mathrm{m}$, on soil. It is not widely distributed or easily found on the island, but is often associated with Lejeunea spp. On the continent it occurs on soil, limestone and rotten wood at low altitudes (to $800 \mathrm{~m}$ ). This species differs from Fissidens hornoschuchii by the leaf margin and smooth leaf cells. In Brazil it is reported from Acre, Alagoas, Amapá, Amazonas, Bahia, Ceará, Distrito Federal, Espírito Santo, Goiás, Maranhão, Mato Grosso, Mato Grosso do Sul, Minas Gerais, Pará, Paraíba, Paraná, Pernambuco, Piauí, Rio de Janeiro, Rio Grande do Sul, Rondônia, Roraima, Santa Catarina, São Paulo and Tocantins.

Specimens examined. Brasil. Ilha da Trindade: Ponta Verde, 27/II/11, Faria 331 (UB); leito do córrego na trilha da Ponta do Noroeste, 28/II/11, Faria 420 (UB).

\section{Leucobryaceae}

Campylopus fragilis subsp. fragiliformis (J.-P. Frahm) J.-P. Frahm., Bryol. Beitr. 7: 97. 1987.

Campylopus fragilis has two subspecies in the neotropics, but only Campylopus fragilis subsp. fragiliformis occurs in Brazil (Frahm 1991, Costa et al. 2011). Subspecies fragilis occurs in montane forest in the Andes, the high alpine belt in Mexico, Guatemala, Costa Rica, Cuba, Jamaica, Puerto
Rico, Haiti, Venezuela, Colombia, Ecuador, Haiti, Peru and Bolivia, and also in North America, Europe, tropical Africa and SE Asia (Frahm, 1991). Frahm (1991) suggested that this distribution is the result of a vicariant event.

Campylopus fragilis subsp. fragiliformis is endemic to Brazil and is found only in fragmented areas of Atlantic Forest in the states of Minas Gerais and Rio de Janeiro, between 1,500 and $2,500 \mathrm{~m}$, where it inhabits Atlantic coastal fragments on soil and dead logs (see conservation section below). Interestingly enough, it was found on Trindade Island on the edges and inside the giant fern forest, above $300 \mathrm{~m}$. It grows on soil, logs and occasionally on rocks and dead logs. This moss was the only acrocarp found in the forest areas of the island, and was most often associated with Isopterygium tenerifolium.

Specimens examined. Brasil. Ilha da Trindade: Floresta de Samambaias Gigantes, 27/II/11, Faria 335 (UB); Fazendinha, 26/III/11, Faria 606 (UB); Ponta do Noroeste, 28/II/11, Faria 437 (UB).

Campylopus pilifer Brid., Muscol. Recent. Suppl. 4: 72. 1819.

This species has a neotropical distribution. On Trindade it is found on the plateau of Pico do Desejado, above $400 \mathrm{~m}$, on dry soil among grassy vegetation. It forms large populations in open areas during the winter (June to August), but in the summer (December to March) it has a much smaller distribution, occurring only in the shade of grassy vegetation. On the continent it is often found on exposed rocks, soil and on the edges of roads and trails, to $2,500 \mathrm{~m}$. It is easily recognized by its long and hyaline leaf apex.

On the continent this species can range from 0.5 to 5 $\mathrm{cm}$, but, interestingly, on the island it did not exceed $2 \mathrm{~cm}$. In Brazil it is widespread and reported from Alagoas, Amazonas, Bahia, Distrito Federal, Espírito Santo, Mato Grosso, Minas Gerais, Pará, Paraná, Pernambuco, Rio de Janeiro, Rio Grande do Sul, Roraima, and São Paulo.

Specimens examined. Brasil. Ilha da Trindade: platô do Pico do Desejado, 06/VI/10, Faria 66 (UB); Morro Vermelho, 27/II/11, Faria 337 (UB); Ponta do Noroeste, 28/ II/11, Faria 441 (UB).

\section{Pottiaceae}

Barbula indica (Hook.) Spreng., Nomencl. Bot. 2: 72. 1824.

This species has a widespread, pantropical distribution. It is found mostly between $0-1,600 \mathrm{~m}$ on soil, roadsides and other antropic environments. On Trindade it is found mostly on volcanic rocks and only below $100 \mathrm{~m}$. This species has lanceolate to ovate leaves that have similar cells on both surfaces and are papillose to nearly smooth. In Brazil it is recorded from Acre, Amazonas, Bahia, Distrito Federal, Espírito Santo, Mato Grosso, Mato Grosso do Sul, Minas Gerais, Pará, Pernambuco, Rio de Janeiro, São Paulo and Sergipe.

Specimens examined. Brasil. Ilha da Trindade: Pico da Bandeira, Faria 208 (UB); trilha do Pico do Desejado, 16/ 
II/11, Faria 242 (UB); Ponta Verde, 27/II/11, Faria 326 (UB). Hyophiladelphus agrarius (Hedw.) R.H. Zander., Bryologist 98: 372. 1995.

This species has a cosmopolitan distribution. On Trindade it occurs in dry, open places, above $100 \mathrm{~m}$, on soil and volcanic rocks, and is associated with Philonotis uncinata. On the continent it occurs on soil, rocks and house walls, to $100 \mathrm{~m}$. This species has leaves that are oblong-spatulate, and can be differentiated from Barbula indica by its borderless leaves and smooth cells. In Brazil it is reported from Acre, Amazonas, Bahia, Ceará, Distrito Federal, Mato Grosso, Pará, Paraíba, Pernambuco, Rio de Janeiro, Rio Grande do Norte, Rondônia, Roraima, São Paulo, Sergipe and Tocantins.

Specimen examined. Brasil. Ilha da Trindade: Pico Pão de Acúcar, 06/VI/10, Faria 65 (UB).

\section{Pylaisiadelphaceae}

Isopterygium tenerifolium Mitt., J. Linn. Soc., Bot. 12: 499. 1869.

This species has a neotropical distribution and is the only pleurocarp found on the Island where it is restricted to the edges of the giant fern forest, at $400 \mathrm{~m}$, where there is plenty of shade and moisture. It inhabits decaying vegetation from dead ferns, and is also an epiphyte on living ferns and trees but, in this case, never above $1.5 \mathrm{~m}$ on the substrate. This species is easy to identify because it is the only pleurocarp on Trindade and because it lacks or has a short, double costa. On the continent it occurs on soil, tree trunks and dead logs, to $2,120 \mathrm{~m}$. In Brazil it is reported from Amazonas, Bahia, Ceará, Distrito Federal, Goiás, Mato Grosso, Minas Gerais, Pará, Paraná, Rio de Janeriro, Rio Grande do Sul, Rondônia, Roraima, Santa Catarina and São Paulo.

Specimens examined. Brasil. Ilha da Trindade: Floresta de Samambaias Gigantes, 06/VI/10, Faria 92 (UB); Pico do Desejado, 10/III/11, Faria 478 (UB); Sine Loco, 22/X/11, Dittrich 1749 (UB).

\section{Anthocerotophyta}

\section{Anthocerotaceae}

Anthoceros punctatus L., Sp. Pl. 1139. 1753.

This species is the only representative of Anthocerotophyta and has a very wide distribution in the Neotropics. On Trindade it inhabits soil and the beds of streams, in shady areas, to $180 \mathrm{~m}$, and is frequently associated with Riccia membranaceae. In Brazil this species occupies the same substrate and can be found up to $800 \mathrm{~m}$. It can be recognized by its green thallus, which becomes blackish in the herbarium, also by its dark-brown papilose spores, which are rounded-tetrahedral, unicellular, and have a inner surface with a distinct trilete mark. It is present in the states of Amazonas, Bahia, Rio de Janeiro, Rio Grande do Sul, Santa Catarina and São Paulo.
Specimens examined. Brasil. Ilha da Trindade: trilha do Pico do Desejado, 06/VI/10, Faria 103 (UB); leito do córrego na trilha da Ponta do Noroeste, 28/II/11, Faria 429 (UB).

\section{Discussion}

Bryophyte species of Trindade are found mostly above $150-200 \mathrm{~m}$, in field vegetation, which is most likely due to the strong marine spray present at lower altitudes (Alves 1998). This bryophyte flora is composed mostly of widespread species, of which $52 \%$ have a neotropical distribution, $15 \%$ are pantropical, about $21 \%$ have a neotropical and African distribution and the remaining species are cosmopolitan. So most of the species found on Trindade are coming from the American continent, most likely from Brazil.

Brazil has four oceanic islands, Trindade, Fernando de Noronha, São Pedro and São Paulo and Atol das Rocas. Of these, only Fernando de Noronha and Trindade have an exuberant plant population and, according to data presented here, Trindade has the most diverse Bryophyte flora.

The bryophyte flora of Fernando de Noronha was studied by Gepp (1891) and Vital et al. (1991) and it currently comprises 22 species (two hornworts, three liverworts and 17 mosses); the most speciose family is Fissidentaceae. It contrasts with Trindade where Liverworts (Lejeuneacaee) seem to prevail.

The island of Fernando de Noronha is much closer to the continent, (ca. $360 \mathrm{Km}$ from the coast) and is also much bigger than Trindade, which is $15 \mathrm{~K} \mathrm{~m}^{2}$, has an annual precipitation of about $1,300 \mathrm{~mm}$ and reaches $323 \mathrm{~m}$ elevation. The island of Trindade, which is smaller and much more remote, presents a much richer bryophyte community with 32 species (verses 22 on Fernando de Noronha). This could be explained, at least partially, by the much higher altitudes found on Trindade. According to Slack (1977), Gradstein \& Pócs (1989), Frahm \& Gradstein (1991) and Gradstein (1995), the bryophyte richness increases as altitude increases, and Trindade has the unique presence of freshwater creeks and is much more isolated from human impact (caused possibly by the tourism on Fernando de Noronha).

Between these two islands there are only three species in common (Fissidens hornschuchii, F. zollingeri e Hyophiladelphus agrarius), which are all widely distributed mosses.

When compared with the other islands of the South Atlantic, Trindade does not share much similarity with any of them; no species are shared with the islands of Ascencion and Tristan da Cunha and it only has six species in common with São Tomé, four with Saint Helena and three with Príncipe (a more detailed study about this is underway).

Acording to Muñoz et al. (2004), dispersal plays a fundamental role in the distribution patterns in the South Atlantic and floristic similarities of cryptogams could be more related to wind currents. Among the species found on Trindade, 96\% are also found in the Southeast Region of Brazil, for 
example, the pantropical species Calymperes tenerum found on Trindade is found in Brazil only in the Atlantic Forest (Rio de Janeiro and São Paulo). Another good example (discussed below) is Campylopus fragilis ssp. fragiliformis, which also found only in SE Brazil and Trindade.

\section{Implications for conservation}

Campylopus fragilis ssp. fragiliformis is an endemic taxon from Southeast Brazil that is found only in fragmented areas of the Southeast Atlantic Forest, in the states of Rio de Janeiro and Minas Gerais, between 1,500 and 2,500 m. It is also quite rare; there are only ten specimens deposited in Brazilian herbaria and they are from only four localities (Itatiaia, Serra do Caraça, Serra dos Órgãos and Serra do Cipó). Although these localities are somewhat distant (ca. $400 \mathrm{~km}$ from each other), the areas where this species occurs are very small and fragmented.

Also, even though some of those ten specimens are found within protected areas, such as Itatiaia National Park and Serra dos Órgãos National Park, these areas are under severe anthropogenic pressure, including proximity to large urban areas (such as the city of Rio de Janeiro), illegal hunting, illegal land use, and roads (Rocha et al. 2003, IBAMA 2007).

Due to its restricted distribution, the fragmented nature of the region it occurs in, the fact that very few records exist, and according to IUCN (2011) and Hallingbäck et al. (1998), we suggest that Campylopus fragilis ssp. fragiliformis could be included in the Endangered (EN) category (according to B1a,b(iii) criteria). Although the subspecies also occurs on Trindade, the IUCN threat category could still be accepted because the species is rare on the island (only two records).

Considering the importance of the Atlantic Forest as a hotspot of biodiversity, and also its high rate of destruction and fragmentation (Fundação SOS Mata Atlântica \& INPE 2011), the conservation of Trindade Island is important because it can be an alternative host area for taxa like Campylopus fragilis ssp. fragiliformis and others that may be distributed from the Atlantic Forest to the island. This is particularly important now that the vegetation of Trindade is quickly recovering to what is believed to be its original composition (Martins \& Alves 2007). As the vegetation recovers, more substrata and habitats will become available, and, consequently, more bryophytes will be able to establish themselves in Trindade in the near future. These will most likely come from the Atlantic Forest of Southeast Brazil, one of the most threatened biomes on the planet.

\section{Acknowledgements}

The authors thank CNPq for the funding; the Brazilian Navy (Marinha do Brasil) for all of the logistical support; the SECIRM, especially Captains Camilo and Otoch, $1^{\text {st }}$ Naval District, and all the sailors and officers of the Brazilian Navy ships NHi Sirius, NDCC Almirante Saboia, RbAM Almirante Guilhobel and NDD Rio de Janeiro; and the military personnel that maintain the garrison on Trindade. We thank Dr. Denilson Peralta, Dra. Juçara Bordin, and Dr. Ruy Valka Alves for their support and generous help. Thanks especially to the researchers of CPP (Cauê, Juliana, Thaís, André Bembem and Elder) who remained on the island with the first author for two months, and helped in the collection and with the large and difficult trails traveled. The first author also thanks CAPES for the scholarship provided. We also thank Dr. Charles Zartman (INPA) for revising the text.

\section{References}

Almeida, A.; Moreira, L.; Bruno, S.; Thomé.; Martins, A., Bolten, A., \& Bjorndal, K. 2011. Green turtle nesting on Trindade Island, Brazil: abundance, trends, and biometrics. Endangered Species Research 14(3): 193-201.

Alves, R.J.V. 1998. Ilha da Trindade e Arquipélago Martin Vaz - Um Ensaio Geobotânico. Serviço de Documentação. Marinha do Brasil Rio de Janeiro. Diretoria de Hidrografia e Navegação.

Alves, R.J.V. 2006. Terrestrial vascular floras of Brazil's oceanic archipelagos. Pp.83-104. In: Alves, R.J.V. \& Castro, J.W. de A. (Eds.). Ilhas oceânicas brasileiras: da pesquisa ao manejo Brasília, MMA Secretaria de Biodiversidade e Florestas,

Anderson, L.E. 1954. Hoyer's solution as a rapid permanent mounting medium for bryologists. The Bryologist 57: 242-244.

Costa, D.P.; Pôrto, K. C.; Luizi-Ponzo, A.P.; Ilkiu-Borges, A. L.; Bastos, C.J.P.; Câmara, P.A.E.S., Peralta, D.F.; Bôas-Bastos, S.B.V.; Imbassahy, C.A.A.; Henriques, D.K.; Gomes, H.C.S., Rocha, M.L.; Santos, N.D.; Siviero, T.F.; Vaz-Imbassahy, T.F. \& Churchill, S.P. 2011. Synopsis of the Brazilian moss flora: checklist, synonyms, distribution and conservation. Nova Hedwigia 93: 277-334.

Crandal-Stoler, B.;Stoler, R.E.; Long, D.G. 2009. Morphology and classification of the Marchantiophyta. Pp. 1-54. In: Goffinet, B. \& Shaw, A.J. Bryophyte Biology. 2 ed. Cambridge, Cambridge University Press.

Dias R.A.; Agne, C.E.; Gianuca, D.; Gianuca, A.; Barcellos-Silveira, A. Bugoni, L. 2010. New records, distribution and status of six seabird species in Brazil. Iheringia, Série Zoologia 100: 379-390.

Frahm, J-P. \& Gradstein, S.R. 1991. An altitudinal zonation of tropical rain forests using bryophytes. Journal of Biogeography 18: 669-678.

Fundação SOS Mata Atlântica \& INPE (Instituto Nacional de Pesquisas Espaciais) Atlas dos Remanescentes Florestais Da Mata Atlântica, Período 2008-2010. São Paulo 2011.

Gepp, A. 1891. Musci \& Hepaticae. Pp. 74-75. In: Ridley, H.N. (Ed.). Notes on the botany of Fernando de Noronha. London, Journal of the Linnean Society of London Botany 27.

Goffinet, B.; Buck, W.R.; Shaw, A.J. 2009. Morphology, anatomy, and classification of the Bryophyta. Pp. 55-138. In: Goffinet, B. \& Shaw, A.J. Bryophyte Biology. 2 ed. Cambridge, Cambridge University Press.

Gradstein, S.R. \& Pócs, T. 1989. Bryophytes. Pp. 311-325. In: Lieth, H. \& Werger, M.J.A. Tropical Rain Forest Ecosystems. Amsterdam, Elsevier Science Publischers B.V.

Gradstein, S.R. 1995. Bryophyte diversity of the tropical rainforest. Archives des Scienses Geneve 48: 91-96.

Gradstein, S.R. \& Costa. 2003. The Hepaticae and Anthocerotae of Brazil. Ney York, The New York Botanical Garden.

Hallingbäck, T.; Hodgetts, N.; Raeymaekers, G.; Schumacker, R.; Sérgio, R.; Söderström, L.; Stewart, N.; Vána, J. 1998. Guidelines for Application of the Revised IUCN Threat Categories to Bryophytes. Lindbergia 23: 6-12.

IBAMA. 2007. Parque Nacional da Serra dos Órgãos. Plano de Manejo. Documento Síntese. Disponível em http://www.icmbio.gov.br/portal/ images/stories/imgs-unidades-coservacao/pm_parna_serra_orgaos_2.pdf, (Acesso em 25/01/2012). 
IUCN. 2011. Standards and Petitions Subcommittee. Guidelines for Using the IUCN Red List Categories and Criteria. Version 9.0. Prepared by the Standards and Petitions Subcommittee.. Downloadable fromhttp:// www.iucnredlist.org/documents/RedListGuidelines.pdf.

Leal, J.H.N. \& Bouchet, P. 1991. Distribution patterns and dispersal of prosobranch gastropods along a seamount chain in the Atlantic Ocean. Journal of the Marine Biological Association of the United Kingdom 71: 11-25.

Martins, L.S.G. \& Alves, R.J.V. 2007. Regeneração Natural do Morro Vermelho, Ilha da Trindade.Revista Brasileira de Biociências 5(1): 39-41.

Muñoz, J.; Felicísimo, A.M.; Cabezas, F.; Burgaz, A., \& Martínez, I. 2004. Wind as a long-distance dispersal vehicle in the Southern Hemisphere. Science 304: 1144-1147.

Pinheiro, H.T. \& Gasparini, J.L. 2009. Peixes recifais do complexo insular oceânico Trindade-Martin Vaz: novas ocorrências, atividades de pesca, mortandade natural e conservação. Pp. 135-153. In: Mohr, L.V.; Castro, J.W.A.; Costa, P.M.S. \& Alves, R.J.V. (Orgs.). Ilhas oceânicas brasileiras: da pesquisa ao manejo. Vol. II. Brasília, MMA Secretaria de Biodiversidade e Florestas.

Rangel, D.M.F.V.; Oliveira, D.B., Ramos, R.P. \& Muniz, M.J.W. 1988. Caracterização preliminar do meio ambiente do Arquipélago de Fernando de Noronha e relatório das atividades em andamento do Departamento de Meio Ambiente e Turismo. Departamento de Meio Ambiente e Turismo, Secretaria de Meio Ambiente, Produção e Obras, Governo do Território Federal de Fernando de Noronha, Fernando de Noronha, PE, Brasil.
Renzaglia, K.S.; Villarreal, J.C. \& Duff, R.J. 2009. New insights into morphology, anatomy, and systematics of hornworts. Pp. 139-171. In: Goffinet, B. \& Shaw, A.J. 2 ed. Bryophyte Biology. Cambridge, Cambridge University Press.

Rocha, C.F.D.; Bergallo, H.G.; Alves, M.A.S. \& Sluys, M.V. 2003. A biodiversidade nos grandes remanescentes de florestais do estado do Rio de Janeiro e nas restingas da Mata Atlântica. São Carlos, RIMA.

Serafini, T.Z.; França, G.B.D. \& Andriguetto-filho, J.M. 2010. Ilhas oceânicas brasileiras: biodiversidade conhecida e sua relação com o histórico de uso e ocupação humana. Journal of Integrated Coastal Zone Management 10(3): 281-301.

Silva, N.G. \& Alves, R.J.V. 2011. The eradication of feral goats and its impacto in plant biodiversity - a milestome in the history of Trindade Island, Brazil. Rodriguesia 62(3): 717-719.

Slack, N.G. 1977. Species diversity and community structure in bryophyte: New York State studies. Bulletin of New York State Museum 428: 1-70.

Yano, O. 2011. Catálogo de musgos brasileiros: literatura original, basiônimo, localidade-tipo e distribuição geográfica. Publicações online do Instituto de Botânica. Available at http://www.ibot.sp.gov. br/publicacoes/virtuais/musgos\%20brasileros\%20completo\%2023-05. pdf (Acesso em 25/01/12).

Vital, D.M.; Giancotti, C. \& Pursell, R.A. 1991. The bryoflora of Fernando de Noronha. Tropical Bryology 4: 23-24 